\title{
The Role of Tourism Activity in Economic Growth by Using Some Econometric Models Evidence from Jordan
}

\author{
Mohammad H. Saleh ${ }^{1}$, Adnan Turki Garaibeh ${ }^{1}$, Ali Shehadeh ${ }^{1} \&$ Jamil J. Jaber ${ }^{1}$ \\ ${ }^{1}$ Department of Risk Management \& Insurance, The University of Jordan, Aqaba, Jordan \\ Correspondence: Mohammad H. Saleh, Department of Risk Management \& Insurance, The University of Jordan, \\ Aqaba, Jordan. E-mail: mohsaleh1966@yahoo.com
}

Received: January 24, 2019

Accepted: February 24, 2019

Online Published: May 23, 2019

doi:10.5539/mas.v13n6p1

URL: https://doi.org/10.5539/mas.v13n6p1

\begin{abstract}
Tourism is used as a vital strategy to reach greater economic productivity. The aim of this paper is to investigate the dynamic relationship between touruism growth and economic growth, using annual time series data from Jordan over the period (1990-2016). The study used a variety of methods based on the cobb-Douglus production function, the Koyck geometrical lag model, cointegration analysis, error correction model and causality analysis. We reveal if tourism leads to economic growth or growth leads to tourism development or bidirectional relation exists between two variables. According to the results, there are moderately increasing return to scale in tourism sector. In addition to there is a positive long-term equilibrium relation related to growth with both fixed assets and tourism balance. The results of the Granger causality test have demonstrated the unidirectional hypothesis, where tourism development leads to economic growth. This paper presented a set of suggestions that would improve Jordan's competitiveness in tourism.
\end{abstract}

Keywords: economies of scale, return to scale, balance tourism, fixed asset, Granger causality, cointegration, Koyck model

\section{Introduction}

Tourism activity plays an important role in achieving a high level of economic development in economic today. It is a major source of income in Jordan. Jordan's gross domestic product (GDP) includes $7.5 \%$ of the tourism sector. The tourism sector is a vital service sector and the fastest-growing sector in the world.

Recently, Jordanian has considered tourism as a unique economic activity to stimulate the development of overall economy. The Jordanian Strategic Plan for the Tourism Sector (2018-2022) focused on the development of the tourism sector in order to improve the competitiveness of the Jordanian economy and sustain its growth.(Minstry of Tourism-Jordan).Jordanian economy is suffering from many problems associated with structure of macroeconomics represent of deficit in balance of trade, deficit in balance of payments, high unemployment,limited foreign earninings, poverity,high inflation and external shocks. thus, The Jordanian government determine tourism as a key sector to stimulate economic performance by improving efficiency and increasing productivity.Tourism sector can play effective role to help policymakers by increasing tourism receipt,creat positive externality backward and forward linkages to other economic sectors.(cernat and gourdon 2012),(Tugcu 2014). It expands investment opportunities and creats positive return to scale and scope (croes 2006).

In addition to mention, Tourism sector can play substantial impact on economic growth by accumulating foreign exchange earninings, destroying poverity, promoting export trade and attracting foreign direct investment. (Scheyvens and Russell 2012). Economists believe that the fast growth of the tourism sector sustains the growth of national income and enhancement in the balance of payments. (Oh 2005). This paper aims to explain the type of causal relation between tourism activity and growth and investigates the sources of economic growth by estimating the cobb-douglus production function of tourism service sector, also this paper estimates determinants of growth by using Koyck distributed lag model.

Balaguer and Cantavella-Jorda (2002) was the first person who examin hypothesis that the tourism led growth. (Tugcu 2014). Tourism sector affects growth by various cannels first, Tourism provides the necessary funding that helps to cover the deficit of balance of payments. (Nowak et al 2007)؛ second, tourism plays important role in investment,creats best opportunities jobs in hotels, resturants, complementary sectors and supporting activities 
such as transport, travel and shipping agencie؛Third, Tourism stimulates the attraction of foreign direct and indirect investment, and localization of modern technology؛ (Cernot and Gourdon 2012), (Spurr 2009). fourth, Tourism stimulates the establishment of industries related to the tourism sector such as handicrafts, traditional, flower industry and sand glass! fifith, tourism creats backward and forward Linkeges, economies of scope and encourages vertical integration between industries. (croes 2006).

The main hypothesis in this paper explores the contribution of Jordan tourism to economic growth by determining the direction of its relationship.

Above stated the study problem, the rest of the paper includes part 2 consists of economic studies and literature associated with the study. Part 3 presents the data and Methodology. Part 4 Discuss and analysis the results of econometric method, Lastly part 5 conclusion and recommendations.

\section{Literature Review}

There is a large number of studies at the global level that examine the linkages between tourism and economic growth. The tourism sector is a major component of Jordan's GDP and contribute to its development. Several studies have examined the existence of unidirectional causality links the growth of tourism activity with the high levels of economic growth (Brida, Lanzilotta and Pizzolon 2016), (Devitra and Kyaw 2016), (Husein and Kara 2011). This hypothesis show that increases in tourist number, increases in tourist receipts, increases in balance tourist lead to increases in national income and increases investment tourism industry which stimulates economic growth by creating new jobs, inducing backward and forward linkeges between tourism and other sectors. Ivanov and Webster (2013) emphasized the one-way relationship by demonstrating the positive role of tourism on real growth in one hundred and sixty-seven nations.Bouzahasah and EI Menyari (2013) have proven the validity of this hypothesis in the short-run in both Tunisia and Morocco, while the relationship is reflected in the long term.Ohlan (2017) confirmed unidirecional causality which related tourism activity to economic growth and positive impact between financial development and tourism in indian. Chulaphan, and Barahona (2018) investigated whether the expansion of tourism activity contributed to the economic growth of Thailand or an inverse relationship where the economic growth in Thailand leads to the growth of tourism sector, This study were used time series techniques, cintegration and causal tests Granger.

In contrast, other studies favor that economic growth led to tourism growth (Aslan 2013), The reversed hypothesis refer to economic growth causes tourism development suggest that increase capital investment in all sectors in the economy motivates increases in tourist demand and lead to tourist development. On the other hand, number of studies uphold for bidirectional causality which suggest that interdependent and complementary between economic growth and tourism development. This assumption can be explained by interactions between tourism and other sectors of the economy, so that the investments in tourism industry motivates overall economic growth and vice versa. (Lean and Tang 2010), (Ridderstat et al 2014), (Brida et al 2015), (Seghir et al 2015), (Tang and Ozturk 2017).

Other studies revealed no causality between tourism growth and economic growth such as:

(Merida and Golpe 2016), (Tugcu 2014). The neutrality hypothesis due to the growth in tourism independent from economic growth and the tourism is not vital component of overall economic activites.Few studies found that there is negative relationship between tourism development and growth, these studies due to dutch disease (Mieiro and Ramos 2010).

Studies conducted for the Middle East countries such as (Tang and Abosedra 2016) examined hypothesis the tourism are driving growth for Lebanon, the results found the tourist led growth. Kreishan (2010) examined the effect of tourism on economic growth in Jordan, the main finding refer to unidirectional causality. Razaq and Masarwah (2006) explained the impact of tourism sector on the Jordaian economy. The main result is the tourism receipts played vital role in the most important economics variables. Divino et al (2015) analyzed the Brazilian tourism Cobb-Douglas production function. Hamidatou Nacer \& Nasr Hamidatou (2015) investigated impact of tourist activity in Algeria on economic growth by using the cobb Douglus production function method.

The most important characteristic of this study is comprehensiveness and the use of three econometrics methods linked to the study goal, which is unique in using Koyck geometrical distributed lag model. 
Table 1. Selected Literature review, Tourism led economic Growth Hypothesis uni-directional

\begin{tabular}{ll}
\hline Auther & period \\
\hline Zortuk & 2009 \\
Payne and Mervar & 2010 \\
Brida, Jimenez and Pulina & 2016 \\
Tang and Tan & 2013 \\
Bandula and Jayathilake & 2013 \\
Belloumi & 2010 \\
Kibara,Odhiambo and Njuguna & 2012 \\
Bouzahzah and El Menyari & 2013 \\
Deng,Ma and Shao & 2013 \\
Kareem & 2013 \\
Lee and Brahmasrene & 2013 \\
Dritsakis & 2013 \\
Fayissa,Nsiah and Tadasse & 2008 \\
Jin & 2011 \\
Katircioglu & 2010 \\
Surugiu & 2013 \\
Isik & 2012 \\
Katircioglu & 2009 \\
Zuo and Huang & 2017 \\
Li,Jin and Shi & 2018 \\
\hline
\end{tabular}

Table 2. Selected Literature review -Interdependendet between tourism and growth (bidirectional)

\begin{tabular}{lc}
\hline Auther & period \\
\hline Gharttey & 2013 \\
Corrie, stoeckl and Chaiechi & 2013 \\
Lee and Kwag & 2013 \\
Trang,Duc and Dund & 2013 \\
Aslan & 2013 \\
Apergis and Payne & 2012 \\
Nissan, Galindo and Mendez & 2011 \\
Lee and Chien & 2008 \\
Khalil,Mehmood and Waliullah & 2007 \\
Dogru and Bulut & 2018 \\
\hline
\end{tabular}

\section{Data and Methodology}

The aim of this paper is to revealed and investigated the dynamic relationship between tourism growth and economic growth in Jordan for the period starting from 1990 and finishing 2016. This study uses annual data on variables Real gross domestic product(RGDP) Which measuers overall economic growth of the Jordan,Labour(L) is expressed of Labour cost,Capital or Fixed Assets(FA)is expressed of average book value of fixed assets,Balance tourism(BT)is expressed of the difference between receipts and expenditures of the tourism. The time series data of RGDP,L,FA,BT Variables on annual bases have been coolected from the Jordanian department of statistics 
(DOS), data base on Jordanian economy and from tourism statistics published by Ministry of tourism, government of Jordan.

Three econometric methods were used to identify the relationship between tourism and economic growth:

3.1 Estimate cobb-Dogluas production function of tourism services by using annual data of value added in tourism sector, Labour component was expressed of Lobar costs, Capital or Fixed Assets was expressed of Average book value of fixed assets. The objective was to measure economies of scale in the tourism sector and identify sources of growth related to tourism.

Value added $=\mathrm{A} L^{\alpha} K^{\beta}$

3.2 This paper uses geometrical distributed lag model (Koyck Method) to establish the dynamic Link between receipts tourism and economic growth.

Koyck model assumes that the weights of independent variables lagged in time are gradually decreasing with geometric progression according to the law:

$$
\begin{gathered}
\beta j=\beta o \delta^{i} \\
0<\delta<1
\end{gathered}
$$

Where $\delta:$ Coefficient of deceleration or response speed.

$\beta j$ : constantly decreasing, $\delta<1$ as time passes.

The effect of the time lag variable decreases on the dependent variable.

Koyck ingenuous model of lag variables is derived from the original model, Which contains only a lag variable exogenous variable, according to this formula:

$$
\begin{aligned}
& \mathrm{Yt}=\mathrm{a}+\mathrm{B} 0 \mathrm{Xt}+\mathrm{B} 1 \mathrm{Xt}-1+\mathrm{B} 2 \mathrm{Xt}-2+-\cdot--------+\mathrm{B} 5 \mathrm{Xt}-5+\mathrm{Ut} \\
& \mathrm{Ut} \sim N\left(0, \sigma^{2}\right) \\
& \mathrm{Yt}=\mathrm{a}+\mathrm{B} 0 \mathrm{Xt}+\delta \mathrm{B} 0 \mathrm{Xt}-1+\delta^{2} \mathrm{~B} 0 \mathrm{Xt}-2+-\cdot-\cdot--\cdot--\cdot--\cdot---\cdot---+\mathrm{Ut}
\end{aligned}
$$

To make model lag one period:

$$
\mathrm{Yt}-1=\mathrm{a}+\mathrm{B} 0 \mathrm{Xt}-1+\delta \mathrm{B} 0 \mathrm{Xt}-2+\delta^{2} \mathrm{~B} 0 \mathrm{Xt}-3+-------------------+\mathrm{Ut}-1
$$

Multiply terms of Equation on $\delta$

$$
\delta Y t-1=\delta \mathrm{a}+\delta \mathrm{B} 0 \mathrm{Xt}-1+\delta^{2} \mathrm{~B} 0 \mathrm{Xt}-2+\delta^{3} \mathrm{~B} 0 \mathrm{Xt}-3+-\cdot-\cdot--\cdot-\cdot-\cdot--\cdot-\cdot---+\delta U t-1
$$

Subtract Equation 4 from Equation 2

$$
\begin{gathered}
\mathrm{Yt}-\delta \mathrm{Yt}-1=\mathrm{a}-\delta a+\mathrm{B} 0 \mathrm{Xt}+\mathrm{Ut}-\delta U t-1 \\
\mathrm{Yt}-\delta \mathrm{Yt}-1=\mathrm{a}(1-\delta)+\mathrm{B} 0 \mathrm{Xt}+\mathrm{Ut}-\delta \mathrm{Ut}-1 \\
\mathrm{Yt}=\mathrm{a}(1-\delta)+\mathrm{B} 0 \mathrm{Xt}+\delta \mathrm{Yt}-1+\mathrm{Vt} \\
\mathrm{New} \text { Error term is } \mathrm{Vt}=(\mathrm{Ut}-\delta \mathrm{Ut}-1)
\end{gathered}
$$

Thus Koyck model after omit constant term became:

$$
\mathrm{Yt}=\mathrm{BoXt}+\delta \mathrm{Yt}-1+\mathrm{Vt}
$$

3.3 This section aims to examin if the tourism activity drive economic growth or vice versa or has a neutral effect or that there is a bidirection relationship between them. The analysis is carried out using the method of cointegration and the error correction model, by estimating the long-term relationship between economic growth and its determinants (tourism-related study variables) and by Granger's causality test.

\section{Discuss and Analysis the Results}

\subsection{Production Function Model}

Analysed Production function methods have been based on statistical data from (1990-2016)

$\mathrm{Q}$ : is output or value added in tourism sector

$\mathrm{L}$ : is Labour cost in tourism sector

$\mathrm{K}$ : is capital (Fixed assets) in tourism sector.

$\log v a l=\log a+b \log L+c \log K$ 


$$
=-.015+1.22 \log \mathrm{L}-0.08 \log \mathrm{k}
$$

$\mathrm{t} \quad(-1.0) \quad(26.1) \quad(-3.5)$

$R^{2}=0.90, \mathrm{~F}=671.1, \mathrm{D} . \mathrm{W}=1.72$

We can conclude from this result that the tourism sector has increasing return to scale at moderate rate which equal (1.30). This result is consistent with its findings of Shi(2011)who shows that there is evidence of increasing returns in transport, retail trade and recreational services at the tourism industry in Ausralian.( Shi and Symth 2011).

4.2 (Koyck Method) Geometrical Distributed Lag Model

$\mathrm{Yt}=\mathrm{B} 0+\mathrm{B} 1 \mathrm{Yt}-1+\mathrm{B} 2 \mathrm{Rt}+\mathrm{Ut}$

Rt: Return or Receipt tourism.

Yt:Real gross demostic product.

$\mathrm{RGDP}=527.3+0.27 \mathrm{Rt}+0.86 \mathrm{Yt}-1$

$\begin{array}{llll}\mathrm{t} & 3.3 & 2 & 15.9\end{array}$

P-value $0.002 \quad 0.05 \quad 0.0000$

$\mathrm{Yt}=\alpha *+\mathrm{B} \mathrm{Rt}+\partial \mathrm{Yt}-1+\mathrm{Vt}$

$a^{*}=\alpha(1-\delta)$

We can get the estimation of value parameter of lag variable and represent the short-run impact of tourism Which equal $=0.27$

1) The long-run impact calculate according to this Formula:

$\mathrm{LR}=a^{*} \div(1-\partial)=527.3$

An increase of $10 \%$ in tourism revenue leads to an increase in Real gross domestic product of $52.73 \%$ over the long term.

2) impact in short run:

a) Median $\operatorname{lag}=\log 2 \div \log \partial=4.6$ approxmatly four months.

Represent the time required for $50 \%$ from change $\mathrm{Yt}$ as result of change of Rt by one unit.

b) Average Lag $=\partial \div 1-\partial=6.14 \sim$ six months, measures the speed of response to changes in tourism receipt Which equal six months.

c) variance $\operatorname{Lag}=\partial \div 1-\partial^{2}=0.86 \div 1-0.2604=3.3$ months.

The variation in the lag period is expressed by the difference between the actual period and the estimated period.

d) intercept $a^{*}=\alpha \div(1-\partial)=527.3 \div(1-0.86)=3766.4$

e) The weights of lag variables compute as formula: $\mathrm{Wi}=(1-\partial)^{i}$

$\mathrm{W} 1=0.14, \mathrm{~W} 2=0.02$

We can note that with two years, tourism receipt contributes $16 \%$ to real GDP Change.

The Koyck model was estimated based on estimated informat and weights as follows:

$\mathrm{Yt}=3766.4+0.270 \mathrm{Rt}+0.14 \mathrm{Yt}-1+0.02 \mathrm{Yt}-2+\mathrm{Vt}$

4.3 As an important stage of time series Practical test, In the beginning we define the degree of integration for each variable followed in the study. The unit root stationary test and the Dicky - Fuller test were used for this goal . The findings of these tests are shown in Table (3). Since the values of the ADF statistic are less than the critical value at a significant level of 5\%, we reject the null hypothesis that there is no root unit . thus, the series is stable at the first difference. hence, the variables are stationary and integrated at first order.

Table 3. Results of stationary and integrated variables

\begin{tabular}{|c|c|c|c|}
\hline $\begin{array}{l}\text { Variables in their First } \\
\text { Differences with Trend } \\
\text { and intercept }\end{array}$ & ADF statistics & Crictical values & Decision \\
\hline
\end{tabular}




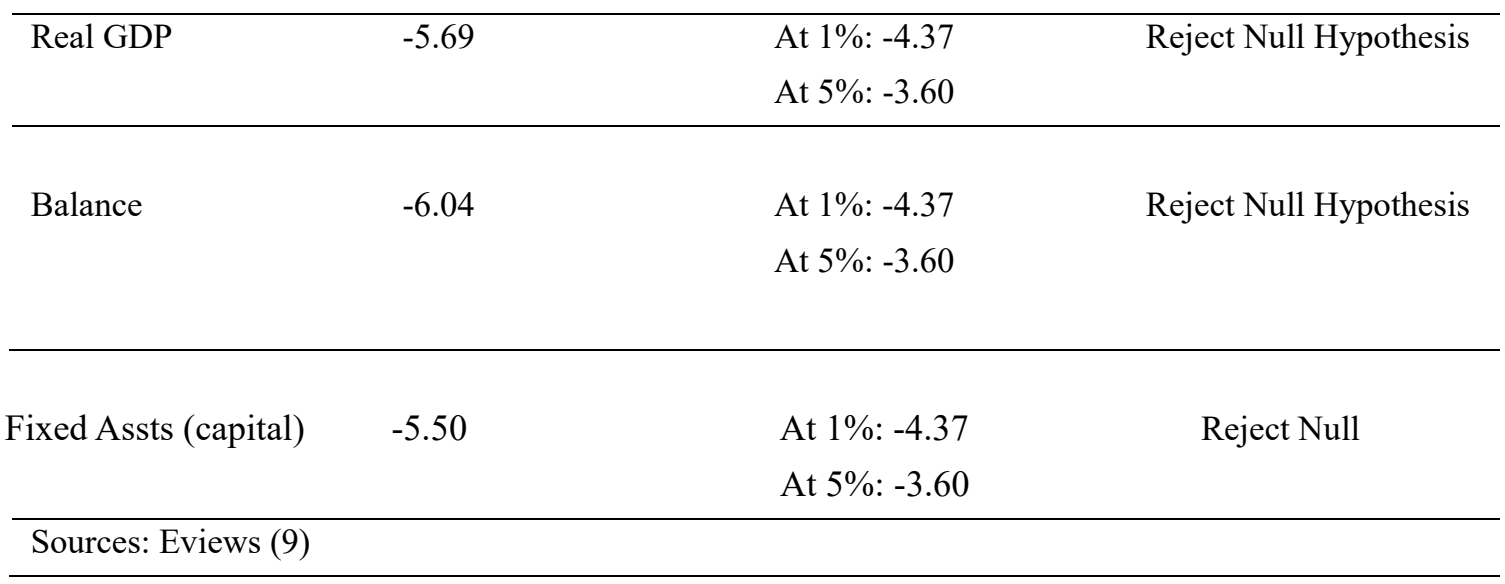

The second stage, Johansens Trace and Maximum Eigenvalue tests have been completed in order to measure the cointegration between stationary variables. Table (3) shows the results of the Dicky- Fuller test. The cointegration equation at $5 \%$ level of significance has been found by trace test. In addition to the maximium eigenvalue test occurs the asseration of this finding. Hence, There is a long -term equilibrium realationship between variables. But in the short-term variances may be occurred, thus, we have to investigate if disturbances coverges to the long term equilibrium or not. The error correction model is used to determine the direction of the causal relationship in the short and long term between variables in the model and to estimate the speed of reaching the long-term equilibrium. Error correction model is a process to addressing the disturbances and matching the relation between short term and long term.

Table 4. Results of Johansens Cointegration test

\begin{tabular}{|c|c|c|c|}
\hline Number of cointegrating & Eigen value & Trace statistics & $\begin{array}{l}\text { Critical value } \\
\text { At } 5 \% \mathrm{P} \text {-value }\end{array}$ \\
\hline \multirow[t]{2}{*}{ *none } & 0.3303 & 29.91 & 29.79 \\
\hline & & & P-value: 0.74 \\
\hline \multirow{2}{*}{ At most 1} & \multirow{2}{*}{0.1558} & \multirow{2}{*}{5.45} & 15.49 \\
\hline & & & P-value: 0.75 \\
\hline \multirow[t]{2}{*}{ At most 2} & \multirow[t]{2}{*}{0.0474} & \multirow[t]{2}{*}{1.21} & 3.84 \\
\hline & & & P-value:0. 27 \\
\hline \multicolumn{4}{|c|}{${ }^{*}$ Denotes rejection of the hypothesis at the $5 \%$ level. } \\
\hline \multicolumn{4}{|c|}{ Table (4) Results of Johansens Cointegration test } \\
\hline \multirow{2}{*}{ Number of cointegrating } & \multirow{2}{*}{ Eigen value } & \multirow{2}{*}{ Maximum statistics } & Critical value \\
\hline & & & At $5 \%$ P-value \\
\hline \multirow[t]{2}{*}{ *none } & \multirow[t]{2}{*}{0.3303} & \multirow[t]{2}{*}{22.16} & 21.13 \\
\hline & & & P-value: 0.74 \\
\hline \multirow{2}{*}{ At most 1} & \multirow{2}{*}{0.1558} & \multirow{2}{*}{4.24} & 14.26 \\
\hline & & & P-value: 0.83 \\
\hline \multirow[t]{2}{*}{ At most 2} & \multirow[t]{2}{*}{0.0474} & \multirow[t]{2}{*}{1.21} & 3.84 \\
\hline & & & P-value: 0.27 \\
\hline
\end{tabular}

We must choose a suitable lag length in order to estimates a vector error correction model (VECM). We should determine number of lags in the model based on Schwaarz information Criterion(SIC). The required length of lag is 2 to reduce (SIC). 
Estimates for VECM Regressions:

$\mathrm{D}(\mathrm{RGDP})=-0.537589$ Ect-0.82 balance $(-1)-0.02 \mathrm{Fa}(-1)-0.52-0.05 \mathrm{RGDP}(-1)+2.12 \mathrm{RGDP}(-2)-0.6$

$\mathrm{t}$

$(0.00017)$

Balance(-1)+0.79Balance(-2)-0.17Fa(-1)+0.13DFa(-2)-0.039

$(-1.11)$.

The adjustment parameter is (-53.76). It indicates that the gross domestic product (GDP) is adjusted in period (t) by $(53.76 \%)$ from the disequilibrium value in the period (t-1) (About 4.5 years) towards its long-term equilibrium value after the impact of the shock in the model. The speed of the adjustment of the equlilibruim is slow.

When gross domestic product (GDP) deviates in the short term from its long-term equilibrium value, the equivalent of $53.76 \%$ of this disequilibrium is corrected in period $(\mathrm{t})$.

The presence of cointegration reveals the presence of Granger Causality at least in one direction. The value of error correction coefficient shows the presence of long-term causality between the variables of the research. The results in table (5) show the unidirectional causality relationship from the balance of tourism and fixed assets in tourism to economic growth.

Table 5. Results of Grangrer Casulity test

\begin{tabular}{lccc}
\hline \multicolumn{1}{c}{ Null Hypothesis } & F-statistics & Probability & Decision \\
\hline $\begin{array}{l}\Delta \text { Balance does not } \\
\text { Granger Cause }\end{array}$ & 2.87 & 0.08 & accept \\
$\begin{array}{l}\Delta \text { RGDP } \\
\Delta \text { RGDP does not }\end{array}$ & 0.65 & 0.53 & accept \\
$\begin{array}{l}\text { Granger Cause } \\
\Delta \text { Balance }\end{array}$ & & & \\
\hline $\begin{array}{l}\Delta \text { Fa does not Granger } \\
\text { Cause } \Delta \text { RGDP }\end{array}$ & 0.05 & 0.95 & accept \\
$\begin{array}{l}\Delta \text { RGDP does not } \\
\text { Granger Cause } \Delta \text { Fa }\end{array}$ & 0.86 & 0.43 & accept \\
$\begin{array}{l}\Delta \text { Fa does not Granger } \\
\text { Cause } \Delta \text { Balance. }\end{array}$ & 0.41 & & accept \\
$\begin{array}{l}\Delta \text { Balance does not } \\
\text { Granger Cause } \Delta \mathrm{Fa}\end{array}$ & 0.91 & 0.67 & \\
\hline Source: researcher & & & accept \\
\hline
\end{tabular}

Source: researcher.

The findings in Table (5) illustrate that all the null-Hypothesis are accepted at 5\% level of significant. These findings confirm the result received from VECM related to the non-presence of short term casualty at significanc $5 \%$.

\section{Conclusion and Recommendations}

Jordan has many potentials and tourism opportunities that qualify it to compete with neighboring countries in the region, It includes all aspects of tourism such as historical tourism and religious tourism. The government plays an important role in providing adequate infrastructure, promoting tourism activity and providing many facilities and logistics services.

Tourism returns are used to import capital goods and fixed assets that are used in the production of goods and services, finance imports and contribute to reducing trade deficit, payments and budget deficit. In addition to tourism investment is encouraged to increase the forward and backward linkages through the establishment of supporting investments such as banks, exchange companies, restaurants, hotels and various entertainment places. All these factors lead to economic growth in the host country. In this paper, a variety of econometric methods, including the time series approach, have been used to illustrate the impact and type of relation between tourism and economic growth in Jordan. Tourism was expressed by the variables of tourism balance and fixed assets, and economic growth was expressed in real GDP. 
The value added in the tourism sector influence of the economic growth in Jordan through the economies of scale of the production function, which were measured in this study and show that it is characterized by increasing return to scale moderately, and this provides opportunities for the tourism sector to exploit the possibilities available to achieve economies os scale, reduce costs and improve competitiveness.

This paper uses geometric distributed lag model (Koyck Method) to establish the dynamic link between receptions tourism and economic growth. the Quick model shows that tourism revenues contribute to a real GDP change of $16 \%$ over two years.

Estimating the long-run equilibrium relation between economic growth and independent variables related to tourism requires verification of the stationary of the time series, the study was used Augmented-Dicky fuller unit root test which demonstrate that all variables series are I(1).

The findings of the cointegration test depend on Johansen s method reveal the presence of the cointegration between variables.thus, The error correction model takes into account the short- and long-term dynamic interaction between economic growth and its determinants. The estimation of vector error correction model depend on VAR reveal the presence of long-term unidirectional casualty running from balance tourism to real GDP in the longterm.

The results of this paper supports the tourism-led growth hypothesis, this applies to a small economy such as the Jordanian economy has some comparative advantages in tourism and attractive investment environment, but this result may vary over time and with other countries. This result is consistent with the long-term and stable relationship between tourism activities and real GDP growth in Jordan. With more clarity, When tourists activites or events increase, the GDP growth rate enhances by increasing in the balance tourism and fixed assets from tourism sector.

The Jordanian tourism sector suffers from many marketing obstacles, promotional aspects of the tourist product, administrative and institutional obstacles, shortage of funding, reduction of tourism investment and fluctuation of return from the tourism industry. The most important challenge is the weak competitiveness of the tourism industry due to the high prices of tourism services compared to other countries, the burden of heavy taxes and poor exploitation of tourism resources.

According to the results and to meet the challenges in the tourism sector, the study adopts a number of recommendations to stimulate the growth of tourism in Jordan :First, the policymaker in tourism sector must set up an integrated tourism promotion plan to attract the largest number of tourists from all over the world by targeting religious tourism such as the Nebo mountain in Madaba, Jordan river, which is the river where Jesus was baptized. Second,Maximizing the returns and benefits of tourism resources by enhancing the quality of national tourism services and enhancing the methods of tourism marketing؛ Third, attracting high-spending foreign tourists; fourth, developing and targeting medical tourism through partnerships with international medical institutions and epromotion;Fifth, Maximize the utilize of agreements with the countries of the world to promote tourist sites in Jordan, attract tourists to these sites and provide discounts for large tourist groups Sixth, Establishment joint projects between the public and private sectors to stimulate tourism investment:Last, Improve the competitiveness of tourism in the Jordanian economy by reducing taxes and fees on tourism activities, as well as decreasing the prices of tourism services.

\section{Referrences}

Adamou, A., \& Clerides, S. (2009). Tourism, Development and Growth: International Evidence and Lessons for Cyprus. Cyprus Economic Policy Review, 3(2), 3-22.

Albaladejo, I. P., Gonzalez-Martinez, M. I., \& Martinez-Garcia, M. P. (2014). Quality and endogenous tourism: An empirical approach. Tourism Management, 41, 141-147.

Algieri, B. (2006). International tourism specialisation of small countries. International Journal tourism Research, Willy Economic Modelling, 44, 142-155.

Al-mulali, U., Fereidouni, H. G., Lee, J. M. Y., \& Mohammed, A. H. (2014). Estimating the tourism-led growth hypothesis: A case study of the Middle Eastcountries. Anatolia: An International Journal of Tourism and Hospitality Research, 25(2), 290-298.

Antonakakis, N., Dragouni, M., \& Filis, G. (2013). Time-Varying Interdependencies of Tourism and Economic Growth: Evidence from European Countries. MPRA Munich Personal Repec Archive, 4875. p1-34.

Aslan, A. (2008). An Econometric Analysis on Economic Growth and Tourism in Turkey. MPRA Munich Personal Repec Archive. p1-11. 
Aslan, A. (2013). Tourism development and economic growth in the amaediterranean countries: Evidence from panel Grainger causality tests. Current Issues in Tourism, 17(4), 363-372.

Aslanturk, Y., Balcilar, M., \& Ozdemir, Z. A. (2011), Time-varying between tourism receipts and economic growth in a small open economy. Economic Modelling, 28(1), 664-671.

Balaguer, J., \& Cantavella-Jorda, M. (2002). Tourism as a long-run economic growth factor: The Spanish case. Applied Economics, 34(7), 877-884.

Balcilar, M., van Eyden, R., \& Inglesi-Lotz, R. (2014). Time-varying linkages between tourism receipts and economic growth in South Africa. Applied Economics, 46(36), 4381-4398.

Bassil, C., Hamadeh, M., \& Samara, N. (2015). The tourism led growth hypothesis: The Lebanese case. Tourism Review, 70(1), 43-55.

Belloumi, M. (2010). The relationship between tourism receipts, real effective exchange rate and economic growth in Tunisia. International Journal of Tourism Research, 12(5), 550-560.

Bouzahzah, M., \& Menyari, Y. (2013). International tourism and economic growth: The case of Morocco and Tunisia. Journal of North African Studies, 18(4), 592-607.

Brida, J. G., Cortes-Jimenez, I., \& Pulina, M. (2014). Has the tourism-led growth hypothesis been validated? A literature review. Current Issues in Tourism. Retrieved from http://www.dx.doi.org/10.1080/13683 500.2013.868414

Brida, J. G., Carrera, E. J. S., \& Risso, W. A. (2008). Tourism's impact on long-run Mexican economic growth. Economics Bulletin, 3(21), 1-8.

Brida, J. G., Lanzilotta, B., Pereyra, J. S., \& Pizzolo'n, F. (2016). A non linear approach to the tourism led growth hypothesis: The case of MERCOSUR. Current Issues in tourism, 18(7), 647-666.

Castro-Nuno, M., Molina-Toucedo, J. A., \& Pablo-Romero, M. P. (2013). Tourism and GDP: A meta-analysis of panel data studies. Journal of Travel Research, 52(6), 745-758.

Cernat, L., \& Gourdon, J. (2012). Paths success: Benchmarking cross-country sustainable tourism. Tourism Management, 33, 1044-1056.

Chen, C., \& Chiou-Wei, S. Z. (2009). Tourism expansion, tourism uncertainty and economic growth: New evidence from Taiwan and Korea. Tourism Management, 30(6), 812-81.

Ding, Du., Ng, P., \& Lew, A. (2016). Tourism and Economic Growth. Journal of Travel Research.

Dogru, T., \& Bulut, U. (2018). Is tourism an engine for economic recovery? Theory and empirical evidence, 67, 425-434. Tourism management,

Dreger, C., \& Reimers, H. E. (2005). Health Care Expenditures in OECD Countries: A Panel Unit Root and Cointegration Analysis, IZA Discussion Paper No. 1469.

Dritsakis, N., \& Athanasiadis, S. (2000). An econometric model of tourist demand: The case of greece. Journal of Hospitality \& Leisure Marketing, 7(2), 39-49.

Ekanayake, E. M., \& Long, A. E. (2012). Tourism development and economic growth in developing countries. The International Journal of Business and Finance Research, 6(1), 51-63.

Ertugrul, M. H., \& Mangir, F. (2015). The tourism-led growth hypothesis: Empirical evidence fromTurkey. Current IssuesinTourism, 18(7), 633-646.

Fawaz, F., \& Rahnama, M. (2014). An empirical refinement of the relationship between tourism and economic growth. Anatolia: An International Journal of Tourism and Hospitality Research, 25(3), 1-14.

Fayissa, B., Nsiah, C., \& Tadasse, B. (2008). The Impact of Tourism on Economic Growth and Development in Africa. Working Papers, 200716. p1-22.

Ghosh, S. (2011). Examining tourism-led growth hypothesis for India. International. Journal of Indian Culture and Business Management, 4(3), 347-355.

Gunduz, L., \& Hatemi, J. A. (2005). Is the tourism-led growth hypothesis valid for Turkey? Applied Economics Letters, 12(8), 499-504.

Gunduz, L., \& Hatemi-J, A. (2005). Is the tourism-led growth hypothesis valid for Turkey? Applied EconomicsLetters, 12, 499-504. 
Holzner, M. (2011). Tourism and economic development: The beach disease? Tourism Management, 32(4), 922933.

JLL (Jones Lang LaSalle). (2012). Sub-Saharan Africa: A region with opportunities a mid transparency challenges. London: JLL.

Jordanian Ministry of Tourism and Antiquities, various reports $(2015,2016,2017)$.

Katircioglu, S. T. (2009). Testing the tourism-led growth hypothesis: The case of Malta. Acta Oeconomica, 59(3), 331-343.

Kim, H. J., Chen, M. H., \& Jang, S. S. (2006). Tourism expansion and economic development: The case of Taiwan. Tourism Management, 27(5), 925-933.

Kizilgol, O., Erbaykal, E. (2008), The relationship between tourism revenues and economic growth in Turkey: A causality analysis. Suleyman Demirel University. The Journal of Economics and Administrative Sciences, 13(2), 351-360.

Kumar, R. R., Loganathan, N., Patel, A., \& Kumar, R. D. (2014). Nexus between tourism earnings and economic growth: A study of Malaysia.1-20. Quality and Quantity. https://doi.org/10.1007/s11135-014- 0037-4

Nowak, J. J., Sahli, M., \& Cortes-Jimenez, I. (2007). Tourism, capital good imports and economic growth: Theory and Evidence for Spain. Tourism Economics, 13(4), 515-536.

Oh, C. O. (2005). The contribution of tourism development to economic growth in the Korean economy. Tourism Management, 26, 39-44.

Ohlan, R. (2017). The relationship between tourism, financial development and economic growth in India. Future Business Journal, 3(2017), 9-22.

Ozturk, I. (2015). The relationships among tourism development, energy demand and growth factors in developed and developing countries. International Journal of Sustainable Development \& World Ecology. https://doi.org/10.1080/13504509.2015.1092000.

Ozturk, I., \& Acaravc1, A. (2009). On the causality between tourism growth and economic growth: Empirical evidence from Turkey. The Transylvanian Review of Administrative Sciences, 25E, 73-81.

Pablo-Romero, M., Molina, J.A.M. (2013), Tourism and economic gowth: A review of empirical literature. Tourism Management Perspectives, 8, 28-41.

Parrilla, J. C., Font, A. R., \& Nadal, J. R. (2007). Tourism and long-term growthaSpanishperspective. Annals of Tourism Research, 34(3), 709-726.

Pavlic, I., Svilokos, T., \& Tolic, M. S. (2015), Tourism, real effective exchange rate and economic growth: Empirical evidence for Croatia. International Journal of Tourism Research, 17(3), 282-291.

Payne, J. E., \& Mervar, A. (2010). The tourism growth nexus in Croatia. Tourism Economics, 16(4), 1089-1094.

Phiri, A. (2016). Tourism and Economic Growth in South Africa: Evidence from linear and nonlinear cointegration frameworks. Managing Global Transitions, 14(1), 31-53.

Samini, A. J., Sadeghi, S., \& Sadeghi, S. (2011). Tourism and economic growth in developing countries: P-VAR approach. Middle East Journal of Scientific Research, 10(1), 28-32.

Scheyvens, R., \& Russell, M. (2012). Tourism and poverty alleviation in Fiji: comparing the impacts of small- and large-scale tourism enterprises. Journal of Sustainable Tourism, 20(3), 417-436.

Schubert, S. F., Brida, J. G., \& Risso, A. (2011). The impacts of international tourism demand on economic growth of small economies dependent on tourism. Tourism Management, 32, 377-385.

Spurr, R. (2009). Tourism satellite accounts. In L. Dwyer \& P. Forsyth (Eds), International Handbook on the economics of tourism (pp.283-299). Cheltenham: Edward Elgar.

Srinivasan, P., Santhosh, K. P. K., \& Ganesh, L. (2012), Tourism and economic growth in Sri Lanka: An ARDL bounds testing approach. Environment and Urbanization ASIA, 3(2), 397-405.

Tang, F., \& Abosedra, S. (2016). Tourism and growth in Lebanon: Newevidence from bootstrap simulation and rolling causality approaches. Empirical Economics, 50(2), 679-696.

Tang, C. F., \& Tan, E. C. (2013). How stable is the tourism-led growth hypothesis in Malaysia? Evidence from disaggregated tourism markets. Tourism Management, 37, 52-57. 
Tang, C. F., \& Tan, E. C. (2015). Does tourism effectively stimulate Malaysia's economic growth? Tourism Management, 46, 158-163.

Tang, C. F., Tiwari, A. K., \& Shahbaz, M. (2016). Dynamic inter-relationships among tourism, economic growth and energy consumption in India. Geosystem Engineering, 19(4), 158-169.

Tang, C. H., \& Jang, S. S. (2009). The tourism-economy causality in the United States: A subindustry level examination. Tourism Management, 30(4), 553-558.

Tugcu, C. T. (2014), Tourism and economic growth nexus revisited: A panel causality analysis for the case of the mediterranean region. Tourism Management, 42, 207-212.

Zuo, B., \& Huang, S. (2017). Revisiting the tourism-led economic growth hypothesis: The case of China. Journal of Travel Research, 1-13.

\section{Copyrights}

Copyright for this article is retained by the author(s), with first publication rights granted to the journal.

This is an open-access article distributed under the terms and conditions of the Creative Commons Attribution license (http://creativecommons.org/licenses/by/4.0/). 